\title{
Hva hindrer sykepleiere i å ivareta søsken til barn med kreft?
}

\section{Tidspress og mangelfulle retningslinjer kan gjøre at søsken til barn med kreft ikke blir tatt godt nok vare på av helsepersonell. Hva kan gjøres bedre?}

\section{Kristine Malm}

Sykepleier

Kirurgisk klinikk, St. Olavs hospital

Ane Skrove Nossum

Sykepleier

Nevrologisk avdeling, Sykehuset i Vestfold

Mary-Elizabeth Bradley Eilertsen

Førstelektor

Institutt for sykepleievitenskap, Høgskolen i Sør-Trøndelag

\section{Barn Kreft Søsken}

\section{Hovedbudskap}

Hensikten med dette prosjektet var å undersøke hva sykepleiere opplever som utfordrende med å ivareta søsken til barn med kreft. Ved å identifisere utfordringene kan det være mulig å implementere tiltak for å ivareta søsken på en tilfredsstillende måte og dermed forebygge mulige negative konsekvenser senere i livet. 
I historien om Mummi og det usynlige barnet står følgende: «Dere vet jo at folk lett kan bli usynlige hvis man skremmer dem ofte nok» (1, s. 166). Sitatet illustrerer at hvis et barn ikke blir sett eller anerkjent, kan det til slutt bli «usynlig».

\section{三 «Når alvorlig sykdom rammer barn, blir hele familien påvirket.»}

Når alvorlig sykdom rammer barn, blir hele familien påvirket (2). Søsken til barn med kreft må gå gjennom en barndom med ekstra belastninger sammenliknet med sine friske jevnaldrende (3). I Norge er det 200 barn som får kreft hvert år (4), 80 prosent av disse barna har søsken (5). Det vil si at de fleste barna som blir lagt inn på sykehus, har ett eller flere søsken.

\section{Søsken er sårbare}

Barn er i utgangspunktet i en sårbar situasjon, og søsken til et barn med kreft er i en spesielt utsatt situasjon. De er avhengige av de voksnes evner til å se deres behov for å føle seg verdsatt og anerkjent (6).

Foreldre til barn med kreft har ofte mer enn nok med egne følelsesmessige reaksjoner og evner kanskje ikke å se søskens behov. Dette underst $\varnothing t t e s$ av en studie som rapporterer at søsken opplever mer emosjonelle forandringer enn hva foreldre selv opplevde at barna hadde (7).

Med store forandringer i familien må sykepleieren som møter familien ha god kunnskap om hvilke behov hele familien har.

\section{Hva sier forskningen?}

Det er forsket mye på hvordan søsken av barn med kreft opplever å ha et sykt søsken (8-11). Forskningen viser at søsken til barn med kreft ofte har negative følelser, atferdsog tilpasningsproblemer, dårlige skoleprestasjoner og somatiske plager samt høyere forekomst av angst.

Studien til Yang med flere (11) viser også at relasjonene til andre mennesker blir påvirket, og at søsken opplever mye kaos i familielivet. 
Barn med kreft har like god livskvalitet som sine friske jevnaldrende tre år etter diagnosen (12). Søsken derimot rapporterer om lærevansker, psykosomatiske plager og andre atferdsproblemer ett år etter diagnosen til det syke søskenet (3), noe som kan understreke behovet for støtte og oppfølging både under og etter behandlingen til det syke søskenet.

I tillegg beskriver to oversiktsartikler (10, 13) at søsken opplever at foreldre kommuniserer mindre med dem enn med det kreftsyke barnet. De beskriver at de får lite informasjon, mangler muligheter til å bes $\varnothing$ ke sitt syke søsken og at deres egne behov som søsken ikke blir møtt $(10,13)$. Sykepleieren har dermed en betydningsfull rolle i å gi god og tilpasset informasjon til både søsken og foreldre.

\section{Hva sier loven?}

Fra 1. januar 2018 ble helsepersonell lovpålagt å ivareta mindreårige søsken til pasienter.

Helsepersonellovens (14) paragraf 10a om barn som pårørende, er nå blitt utvidet til å omhandle søsken, og i tillegg er det kommet en ny paragraf $20 \mathrm{~b}$ som omhandler etterlatte barn. Dette viser at det er $\varnothing \mathrm{kt}$ oppmerksomhet rundt søsken som pårørende.

\section{$\equiv$ «Sykepleieren har ansvar for å fremme god helse og forebygge dårlig helse.»}

Gjennom samhandlingsreformen, helse- og

omsorgstjenesteloven og folkehelseloven har sykepleiernes

ansvar for helsefremming og forebygging fătt større

oppmerksomhet (15-17). Det vil si at sykepleieren har ansvar for å fremme god helse og forebygge dårlig helse.

\section{Sykepleiere skal hjelpe søsken}

I dette perspektivet vil det være naturlig å inkludere søsken til barn med kreft. Sykepleieren har ansvar for å tilrettelegge forholdene best mulig slik at søsken ikke opplever de negative konsekvensene som mange søsken til barn med kreft rapporterer. 
Dette støttes også av Florence Nightingale (18) som mener at mangel på omsorg kan være en trussel mot helsen. Hun beskriver en helhetlig tilnærming til pasienter og deres pårørende som en viktig del av sykepleien (18). Ivaretakelsen av søsken er derfor en viktig og utfordrende sykepleieroppgave.

\section{Hensikten med prosjektet}

Hensikten med dette prosjektet er å unders $\varnothing$ ke hva sykepleiere opplever som utfordrende med å ivareta søsken til barn med kreft. Ved å identifisere utfordringene vil det være mulig å implementere tiltak for å ivareta søsken på en tilfredsstillende måte, og dermed forebygge mulige negative konsekvenser senere i livet.

\section{Metode}

For å unders $\varnothing$ ke hva sykepleiere opplever som utfordrende med å ivareta søsken til barn med kreft gjennomførte vi fire semistrukturerte intervjuer ved en barnekreftavdeling i mars 2019.

Utvalget i denne studien er fire frivillige sykepleiere som er ansatt ved en barnekreftavdeling. De er i ulik alder og har forskjellig erfaring. Tre av sykepleierne har vært fast ansatt på avdelingen i over 22 år, mens den siste har arbeidet ved avdelingen i mindre enn ett år.

Det ble gjennomf $\varnothing$ rt et informasjonsm øte med to av de fire informantene i forkant av intervjuet, og de fikk et informasjonsskriv. De to som ikke var på informasjonsmøtet, fikk samme informasjon før intervjuet.

I forkant av intervjuene ble det gjort etiske overveielser, og alle informantene ble informert om deres rettigheter om frivillighet og anonymitet (19). Et samtykkeskjema ble signert før hvert intervju.

Svarene er anonymisert og behandlet konfidensielt. Studien er godkjent av personvern for forskning, Norsk senter for forskningsdata (NSD prosjekt nr. 58522/3/LT).

\section{Slik foregikk intervjuene}

Dette prosjektet bygger på kvalitativ metode som er et egnet metodevalg da grunnlaget er å oppnå forståelse for informantenes erfaringer og opplevelser (20). I et intervju kan informantene formidle tanker, holdninger og erfaringer. 
I forkant av intervjuene ble det utarbeidet en intervjuguide og gjennomført et testintervju med tilbakemelding fra veilederen (Eilertsen). Intervjuguiden var veiledende, og informantene uttrykte seg fritt uten avbrytning av intervjueren (20).

Intervjuene ble gjennomført på et grupperom på sykehuset.

To av forfattere (Malm og Nossum) var til stede under intervjuene, der den ene intervjuet og den andre noterte og kom med tilleggsspørsmål der det var naturlig. Intervjuene tok omtrent 30 minutter.

\section{Intervjuene ble analysert}

Intervjuene ble tatt opp ved hjelp av båndopptaker og deretter transkribert. Skriftlig rådata ble på 13000 ord. Deretter ble det gjennomført en tematisk analyse, der meningsfortolkning og inspirasjon fra systematisk tekstkondensering ble benyttet som analyseform $(21,22)$.

Intervjuene ble lest igjennom flere ganger, deretter ble de analysert ved å tematisere dataene og dele de opp i naturlige grupper. Til slutt ble de viktigste og mest sentrale temaene samlet i en skildring $(21,22)$.

\section{Resultater}

Alle informantene var enige $i$ at å ta seg av søsken til barn som har kreft er en viktig sykepleieroppgave, og de opplever et stort ansvar for å hjelpe søsken. I tillegg opplevde informantene at alle sykepleierne på avdelingen var opptatt av å hjelpe søsken til barn med kreft. Det var søkelys på at søsken trenger god oppfølging, men at det kunne være vanskelig og utfordrende å gi denne oppfølgingen.

På spørsmål om de ofte var bekymret for søsken til barn med kreft svarte alle at de var bekymret i perioder, og at de var klar over hvilke negative konsekvenser søsken kunne slite med både under og etter behandlingen av det syke barnet. Resultatene er sammenfattet i følgende kategorier:

- Retningslinjer for oppfølging

- Samarbeid med foreldre

- Tidspress 


\section{Retningslinjene for oppfølging av søsken er ikke gode nok}

På spørsmål om hvordan søsken blir ivaretatt på avdelingen er det bred enighet blant informantene. De forteller at oppfølgingen av søsken blir for tilfeldig. De savner klare retningslinjer og en struktur som setter en standard for oppfølgingen.

«Og vi har jo kanskje mer et $\varnothing$ nske om at søsken blir enda mer ivaretatt enn de blir gjort, for vi vet det er viktig da, men vi har ikke et opplæringstilbud slik at vi kan gi de informasjon og bruke samme opplæring som vi gir til pasienter og foreldre.»

På spørsmål om de brukte kartleggingsverktøy aktivt for å kartlegge om det var søsken i familien svarte alle at de ikke brukte det. Selv om de ikke brukte kartleggingsskjema, svarte alle at noe av det første de gjorde når det kom en ny familie til avdelingen var å unders $\varnothing$ ke om det var søsken i familien.

Informantene forteller at de ansatte på avdelingen ikke har endret praksis i forhold til ivaretakelse av søsken som pårørende etter at lovendringen trådte i kraft 1. januar 2018. Alle informantene la vekt på at med et bedre kartleggingsskjema og retningslinjer for bruk av kartleggingsskjemaet vil det forbedre oppfølgingen av søsken.

«Mange kollegaer sier: Det er ikke beregnet på søsken, det er beregnet på passerende til syke voksne. Så det blir brukt som et argument for å ikke fylle ut det skjemaet der ...»

\section{Samarbeidet med foreldrene kan være utfordrende}

Informantene mente at foreldre kunne være en utfordring for at de skulle få gitt nødvendig oppfølging til søsken. For at en sykepleier skal kunne gi informasjon og oppfølging til søsken, må foreldrene gi sitt samtykke til det.

«Ofte er det foreldrene som vil at vi skal vente med å gi søsken informasjon.»

To av informantene fortalte om hendelser der foreldrene har holdt søsken unna sykehuset, til tross for at sykepleierne råder foreldrene til at søsken bør være delaktige i behandlingen. 
«En familie vi har i avdelingen nå, har søskenet vært hos besteforeldrene hele tiden, og vi har gang på gang sagt at de må dele seg slik at en av de er med det minste barnet hjemme, men foreldrene har ikke ville hørt på det.»

\section{Tidspress kan føre til at søsken får lite oppmerksomhet}

Alle informantene mente at de har for lite tid til å ta seg av søsken. De fortalte at det syke barnet fikk mye oppmerksomhet, og at det da kunne være fort gjort å glemme det syke barnets søsken.

«Først så har man et sykt barn, også har man foreldrene, også kommer søsken, da kan de fort gå bort i travelhetene.»

På spørsmål om de gjennomførte organiserte søskensamtaler svarte alle at de ikke gjorde det. En informant pratet om at søsken ofte ville leke, spille og «være normale», og at en utfordring kunne være å «nå inn til dem», dette gjaldt særlig for de mindreårige barna. For å «nå inn» måtte sykepleieren ha god tid, og for eksempel å leke med dem. Da kunne de få verdifull informasjon fra søsken om hvor mye de visste om sykdommen, og om de hadde noen bekymringer.

«Det er tøft å være søsken, det ser vi gang på gang. De sliter med vanskelige tanker som de ikke vil snakke med de voksne om, for de skjemmes over at de er sint på den som er syk for eksempel ... og føler sjalusi ... Da er det viktig at vi har tid til å skape en god relasjon.»

\section{Diskusjon}

Hensikten med denne studien var å unders $\varnothing$ ke hva sykepleiere opplever som utfordrende med å ivareta søsken til barn med kreft.

\section{三 «De synes det er utfordrende å gi den hjelpen som søsken trenger.»}

Hovedfunn viser at sykepleiere i stor grad er opptatt av å

hjelpe søsken som pårørende, men at de synes det er utfordrende å gi den hjelpen som søsken trenger på grunn av mangelfulle retningslinjer, utfordrende samarbeid med foreldre og mangel på tid. 
Med bakgrunn i resultatene er det av stor betydning å se på hvilke tiltak som kan hjelpe sykepleierne til å bedre ivareta søsken. Resultatene blir diskutert og sammenfattet videre i teksten.

\section{Er prosedyrene for lite kjent?}

For å hjelpe sykepleierne å dekke behovet til barn som pårørende er det laget prosedyrer for hvordan barn skal kartlegges, hvilke tiltak som kan settes i gang internt og hvordan man skal samhandle med andre instanser (23).

Funn i dette prosjektet kan tyde på at disse prosedyrene ikke er godt nok kjent blant sykepleierne og ikke implementert i avdelingen. I studien til O'Shea med flere (24) rapporterte også sykepleierne at de opplevde at det var lite retningslinjer å forholde seg til, og at det var en utfordring for ivaretakelsen av søsken som pårørende.

\section{Manglende retningslinjer gjør jobben krevende}

Resultatene i dette prosjektet viser at sykepleierne $\varnothing$ nsker å være til hjelp og å være en ressurs for søsken. Ny praksis og bruk av importert kompetanse må støttes av rutiner, kultur og lederføringer for å slå rot (25). Derfor er det viktig at forholdene legges til rette for at sykepleiere skal kunne gi den nødvendige hjelpen de ønsker til søsken som er pårørende.

Ved mangelfulle implementerte retningslinjer for oppfølging stilles det høyere krav til hver enkelt sykepleier for at ivaretakelsen av søsken som pårørende blir tilfredsstillende.

\section{Oppfølgingen av søsken blir for tilfeldig}

Sykepleierne i dette prosjektet opplevde at oppfølgingen ble for tilfeldig, og at den var basert på sykepleierens erfaring, kunnskap og personlige interesse for temaet.

Med større oppmerksomhet fra ledelsen på implementering av prosedyrer som angår søsken som pårørende, kan det bli enklere for sykepleierne å ivareta søsken. Da vil erfaring og personlig interesse ikke være like styrende for oppfølgingen.

\section{Skjemaet er ikke godt nok}


I prosedyrene utarbeidet på det sykehuset vi besøkte er det laget egen prosedyre for kartlegging av barn som pårørende. Det er laget et forslag til kartleggingssamtale og et eget skjema hvor svarene fra denne samtalen skal dokumenteres i pasientens journal (23).

\title{
三 «Det kom også frem at organiserte søskensamtaler ikke var en del av praksisen på avdelingen.»
}

\begin{abstract}
Sykepleierne i dette prosjektet opplevde at dette skjemaet ikke var tilpasset godt nok til søskens behov som pårørende og derfor ikke ble brukt i stor grad. Det kom også frem at organiserte søskensamtaler ikke var en del av praksisen på avdelingen.
\end{abstract}

Hvis søsken som pårørende ikke blir kartlagt, og de ikke blir tilbudt egne samtaler, kan det være stor fare for at deres behov ikke blir møtt. I studien til Wilkins og Woodgate (10) kommer det frem at søsken ofte opplever at deres behov ikke blir møtt, og at de i mange tilfeller mangler informasjon og muligheter til å bes $\varnothing$ ke det syke barnet.

\section{God oppfølging kan bidra til mestring}

God informasjon og oppfølging kan bidra til en opplevelse av $\varnothing \mathrm{kt}$ forutsigbarhet og $\varnothing \mathrm{kt}$ mestring av livssituasjonen. Dette kan hindre videre belastning, problemutvikling og dempe angst hos søsken som pårørende (26).

I en studie utført av Nicholsen med flere (27) laget de et tilrettelagt bes $\varnothing$ ksprogram for barn av alvorlig syke foreldre og sammenliknet de følelsesmessige reaksjonene med barn som ikke fikk dette tilbudet. Den viste at barn som fikk tilrettelagte bes $\varnothing \mathrm{k}$ hadde signifikant færre negative emosjonelle problemer og atferdsforandringer enn barn som ikke fikk dette tilbudet (27).

Harvik og Svendsen (28) har i sin hovedoppgave i barnesykepleie beskrevet et slikt bes $\varnothing$ ksprogram som er tilrettelagt for søsken til alvorlig syke barn. De skriver at et slikt bes $\varnothing$ ksprogram gir veiledning til sykepleierne i hvordan de kan fremme emosjonell og kognitiv st $\varnothing$ tte til barn både før, under og etter besøket hos det syke søskenet (28). Et slikt besøksprogram ville gitt sykepleierne verdifull tid til å kartlegge eventuelle utfordringer denne familien og søsken kan ha. 


\section{Godt samarbeid med foreldrene er viktig}

For å gi søsken best mulig hjelp vil det være viktig med et godt samarbeid med foreldrene. Siden foreldre kjenner sine barn best, og de har det juridiske ansvaret for barna, er det viktig at sykepleierne skaper gode relasjoner til foreldrene (29).

\section{$\equiv \ll$ Foreldre trenger råd og informasjon om normale reaksjonsmønstre hos søsken.»}

I en studie utført av Kleiber med flere (7) fant de ut at søsken hadde høyere emosjonelle forandringer enn hva foreldrene selv opplevde at barna hadde. Dette kan vise at foreldre trenger råd og informasjon om normale reaksjonsmønstre hos søsken.

\section{Foreldrene skal gi barnet informasjon}

I rundskrivet «Barn som pårørende», som er gitt ut av Helsedirektoratet (26), presiseres det at det meste av informasjonen som skal gis til barna $b \varnothing r$ formidles av foreldrene. Det står videre at samtalen mellom fagpersoner/helsepersonell og foreldre kan fungere som en bevisstgjøring og bør sette foreldrene i stand til å selv ivareta barnets informasjons- og hjelpebehov (26).

Hvis relasjonen bygger på tillit, åpenhet, undring og utforsking i gjensidig respekt, vil det bli lettere for helsepersonellet å gi foreldrene $\varnothing \mathrm{kt}$ forståelse for barnets behov for hjelp og støtte (30).

Denne tilnærmingen kan hjelpe sykepleierne å skape tillit hos foreldrene, noe sykepleierne i dette prosjektet fortalte at de syntes var utfordrende når de skulle ivareta søsken.

$\varnothing \mathrm{kt}$ satsing på relasjonskompetanse og foreldresamarbeid, kanskje i kombinasjon med et bes $\varnothing$ ksprogram (28) som beskrevet over, kan gi bedre ivaretakelse av søsken som pårørende.

\section{Sykepleierne må ha tid til samtaler}

I tillegg beskriver O'Shea med flere (24) i sin studie at sykepleierne opplevde det som utfordrende å skape relasjoner til søsken på grunn av mangel på tid. Dette kommer også godt frem i resultatene av dette prosjektet. Sykepleierne fortalte at det syke barnet fikk mye oppmerksomhet og at søsken kunne bli glemt. 
En av sykepleierne fortalte at hun syntes det var vanskelig å nå inn til søsken, da dette krevde at hun hadde god tid til å sette seg ned og leke med dem, dette gjaldt for de minste barna.

For å fremme en god forståelse av søskens behov, må voksenpersoner lytte til barnas tanker og oppfatninger og svare ærlig og åpent på spørsmål (6). En forutsetning for å få til dette er god tid til samtaler og lek.

Dette st $\varnothing t t e s$ av litteratur, der Kinge (31) skriver om å skape gode relasjoner til barn: «For å kunne skape denne relasjonen synes det nødvendig med tid, erfaring og kontinuitet, slik at en kommunikasjonsprosess skal kunne oppstå» (31).

Dette kan være et argument for at helsepersonell som jobber på en avdeling for barn med kreft, bør ha en hverdag hvor det er tid til å være til stede for pasienter, foreldre og søsken.

\section{Styrker og svakheter ved studien}

Intervjuene ble gjennomført i kjente omgivelser uten ytre forstyrrelser. Vi var på forhånd bevisst på at våre egne holdninger ikke skulle påvirke svarene til sykepleierne.

Diskusjonen baserer seg på resultatene fra intervjuene, relevant forskning og litteratur.

Forskningsartiklene er fra 1993-2018, men selv de eldre artiklene er vurdert til å være relevante da de handler om barns behov i forbindelse med søskens eller foreldres sykdom.

Siden dette er en kvalitativ studie er det få informanter og dermed for lite utvalg til å trekke generelle beslutninger rundt sykepleiers erfaringer med søsken som pårørende, men det kan være et godt bidrag lokalt.

\section{Studien får kliniske implikasjoner}

Vi har presentert resultatene fra prosjektet for ansatte og ledelsen ved avdelingen. De skal bruke funnene våre i sitt arbeid med å lage retningslinjer for oppfølging av søsken til barn med kreft, både på avdelingsnivå og for hele Barne- og ungdomsklinikken. 


\section{Konklusjon}

Dette prosjektet viser at sykepleierne vektlegger ivaretakelse av søsken som pårørende.

Imidlertid opplever sykepleierne det som utfordrende å gi den hjelpen søsken har behov for, og de oppga mangelfulle retningslinjer for oppfølging, lite tid og samarbeid med foreldre som spesielt utfordrende. Sykepleierne opplever dermed at søsken som pårørende er et kompetanseområde som krever erfaring og kunnskap for at søsken skal bli tilfredsstillende ivaretatt.

Bedre implementerte retningslinjer og et godt kartleggingsskjema kan øke sykepleiernes kompetanse om søskens behov, foreldresamarbeid og relasjonsbygging.

$\varnothing \mathrm{kt}$ kompetanse og gode retningslinjer vil redusere utfordringene sykepleierne opplever når de skal ivareta behovene til søsken av kreftsyke barn.

\section{Referanser}

1. Jansson T. Det usynlige barnet og andre fortellinger. Oslo: Aschehoug; 2006.

2. Kreftforeningen. Barn og ungdom med kreft. Tilgjengelig fra: https://kreftforeningen.no/rad-ogrettigheter/barn-og-ungdom/barn-og-ungdom-med-kreft/ (nedlastet 23.11.2020).

3. Lähteenmäki PM, Sjöblom J, Korhonen T, Salmi TT. The siblings of childhood cancer patients need early support: a follow up study over the first year. Arch Dis Child. 2004 nov 1;89(11):1008-13.

4. Barnekreftforeningen. Barnekreft. Tilgjengelig fra: https://www.barnekreftforeningen.no/barnekreft (nedlastet 23.11.2020).

5. Statistisk sentralbyrå. Andelen husholdninger med barn synker. Oslo: Statistisk sentralbyrå; 2016. Tilgjengelig fra: https://www.ssb.no/befolkning/statistikker/familie/aar/201610-28 (nedlastet 28.03.2019)

6. Holmsen M. Samtalebilder og tegninger en vei til kommunikasjon med barn i vanskelige livssituasjoner. Oslo:

Damm; 2004. 
7. Kleiber C, Montgomery LA, Craft-Rosenberg M. Information needs of the siblings of critically ill children. Child Health Care. 1995 Winter;24(1):47-60.

8. Weiner JA, Woodley LK. An integrative review of sibling responses to childhood cancer. J Child Adolesc Psychiatr Nurs. 2018;31(4):109-19.

9. Long KA, Lehmann V, Gerhardt CA, Carpenter AL, Marsland AL, Alderfer MA. Psychosocial functioning and risk factors among siblings of children with cancer: An updated systematic review. Psychooncology. 2018;27(6):1467-79.

10. Wilkins KL, Woodgate RL. A Review of qualitative research on the childhood cancer experience from the perspective of siblings: A need to give them a voice. J Pediatr Oncol Nurs. 2005 nov;22(6):305-19.

11. Yang H-C, Mu P-F, Sheng C-C, Chen Y-W, Hung G-Y. A Systematic review of the experiences of siblings of children with cancer: Cancer Nurs. 2016;39(3):E12-21.

12. Bradley Eilertsen M-E, Jozefiak T, Rannestad T, Indredavik MS, Vik T. Quality of life in children and adolescents surviving cancer. Eur J Oncol Nurs. 2012 apr;16(2):185-93.

13. Malone A, Price J. The significant effects of childhood cancer on siblings: Ashley Malone and Jayne Price discuss a narrative literature review of how young family members respond to a brother's or sister's diagnosis of cancer and subsequent treatment. Cancer Nurs Pract. 2012 mai 11;11(4):26-31.

14. Lov 2. juli 1999 nr. 64 om helsepersonell m.v. (helsepersonelloven) Tilgjengelig fra: https://lovdata.no/dokument/NL/lov/1999-07-0264/KAPITTEL_2\#KAPITTEL_2 (nedlastet 27.10.2020).

15. Helse- og omsorgsdepartementet. Samhandlingsreformen. Rett behandling på rett sted - til rett tid. St.meld.nr 47 (2008-2009). Oslo: Helse- og omsorgsdepartementet, 2009.

16. Lov om kommunale helse- og omsorgstjenester m.m. (helse- og omsorgstjenesteloven) Lovdata. Tilgjengelig fra: https://lovdata.no/dokument/NL/lov/2011-06-24-30

(nedlastet: 10.05.2019). 
17. Lov om folkehelsearbeid (folkehelseloven). Lovdata.

Tilgjengelig fra: https://lovdata.no/dokument/NL/lov/2011-06-

24-2 (nedlastet: 10.05.2019).

18. Nightingale F. Notater om sykepleie. Revidert med tillegg, samlede utgaver. Oslo: Universitetsforlaget; 1997.

19. Dalland O. Metode og oppgaveskriving for studenter. 4. utg. Oslo: Gyldendal akademisk; 2007.

20. Brinkmann S, Tanggaard L. Kvalitative metoder, empiri og teoriutvikling. Oslo: Gyldendal Norsk Forlag; 2012.

21. Malterud K. Systematic text condensation: A strategy for qualitative analysis. Scand J Public Health. 1. desember 2012;40(8):795-805.

22. Tjora AH. Kvalitative forskningsmetoder i praksis. 3 . utg. Oslo: Gyldendal akademisk; 2017.

23. Lorentzen LK, Wold M. Barn som pårørende.

Hoveddokument, ID 30469 - EQS. St. Olavs hospital; 2018.

24. O'Shea ER, Shea J, Robert T, Cavanaugh C. The Needs of siblings of children with cancer: A nursing perspective. $\mathrm{J}$ Pediatr Oncol Nurs. 2012 jul;29(4):221-31.

25. Blogg B. Er ikke barn viktige nok? BarnsBeste fagblogg. 2014. Tilgjengelig fra:

https://barnsbesteblogg.com/2014/04/08/er-ikke-barn-viktigenok/ (nedlastet: 28.10.2020).

26. Helsedirektoratet. Barn som pårørende.

Helsedirektoratet; 2010.

27. Nicholson AC, Titler M, Montgomery LA, Kleiber C, Craft MJ, Halm M, et al. Effects of child visitation in adult critical care units: a pilot study. Heart Lung J Crit Care. 1993 feb;22(1):36-45.

28. Hartvik B, Svendsen AK. Sårbare søsken. Sykepleien. 2007. Tilgjengelig fra: https://sykepleien.no/forskning/2007/11/sarbare-sosken (nedlastet 10.05.2019).

29. Lov om barn og foreldre (barnelova). Lovdata. Tilgjengelig fra: https://lovdata.no/dokument/NL/lov/1981-O4o8-7 (nedlastet 06.05.2019). 
30. Kinge E. Hvor er hjelpen når den trengs? Om

relasjonskompetanse. Om foreldresamarbeid. Oslo:

Gyldendal akademisk; 2009.

31. Kinge E. Barnesamtaler: det anerkjennende samværet og samtalens betydning for barn med samspillsvansker. 2. utg.

Oslo: Gyldendal akademisk; 2016. 291 p. 